\title{
WEBINAR PEMBELAJARAN DARING MATEMATIKA DALAM SEPAKBOLA
}

\author{
1)Andriadi \\ ${ }^{2)}$ Ari Suningsih \\ ${ }^{3 *}$ Yudi Yunika Putra
}

\author{
1)Program Studi Pendidikan Jasmani Kesehatan Rekreasi \\ Fakultas Keguruan Ilmu Pendidikan Universitas Muhammadiyah Bangka Belitung \\ 2)Program Studi Pendidikan Matematika, Fakultas Keguruan Ilmu Pendidikan \\ Universitas Muhammadiyah Pringsewu Lampung \\ 3)Program Studi Pendidikan Matematika, Fakultas Keguruan Ilmu Pendidikan \\ Universitas Muhammadiyah Bangka Belitung \\ Jl. KH A Dahlan, Mangkol, Kec. Pangkalan Baru, Kabupaten Bangka Tengah \\ Kepulauan Bangka Belitung 33684 \\ yudi.yunikaputra@unmuhbabel.ac.id
}

\begin{abstract}
ABSTRAK
Dalam pembelajaran matematika dapat menggunakan konteks keseharian yang akrab dan disenangi oleh siswa. Penggunaaan konteks dalam pembelajaran matematika dapat meningkatkan motivasi dan apresiasi yang akan berpengaruh terhadappeningkatan prestasi belajar. Bidang sport atau olahraga khususnya sepakbola merupakan salah satu bidang yang digemari hampir oleh setiap siswa. Menggunakan konteks sepakbola dalam pembelajaran matematika, baik sebagai sumber belajar maupun rekreasi matematika dapat membantu meningkatkan rasa ingin tahu, berpikir reflektif/kritis, dan tentu saja apresiasi terhadap matematika. Ada banyak aspek matematika di dalam permainan sepakbola (Soccer atau Football). seperti topik bilangan, geometri hingga peluang yang dapat dibelajarkan dengan topik sepakbola. Namun permasalahan selama ini ilmu matematika dan ilmu olahraga disampaikan secara masing-masing. Padahal dalam pembelajaran matematika dapat menggunakan konteks olahraga sepakbola. Metode yang digunakan dalam kegiatan ini menggunakan metode daring/online dengan melakukan webinar menggunakan Platform Zoom. Untuk merealisasikan metode tersebut melakukan tahapan atau tahapan, yakni, 1) Perencanaan, 2) Pelaksanaan, dan 3) Evaluasi. Tujuan dari program ini adalah memberikan pemahaman tentang relevansi antara pembelajaran matematika dikaitkan dengan konteks olahraga sepakbola. Hasil yang didapatkan dari kegiatan ini bahwa peserta menyatakan puas dengan kegiatan yang dilakukan, mendapatkan pengetahuan bahwa dalam pembelajaran matematika dapat dikaitkan dengan konteks permainan sepakbola.
\end{abstract}

Kata Kunci : Matematika; Sepakbola; Webinar.

Copyright (C) 2021, Jurnal Batoboh, ISSN 2548-5458 (print), ISSN 2599-1906 (online) 


\section{PENDAHULUAN}

Bidang olahraga khususnya olahraga sepakbola merupakan salah satu bidang yang hampir digemari oleh setiap mahasiswa (Purwanti \& Yusuf, 2018). Sepak bola adalah olah raga yang dimainkan dilapangan oleh dua regu atau dua kesebelasan dengan tujuan memasukan bola atau gol ke gawang lawan (Handoko, 2018). Sepakbola sangat digemari semua kalangan baik kalangan pelajar, masyarakat dan mahasiswa. (Nugrahadi et al., 2018). Bidang olahraga adalah salah satu konteks yang dapat digunakan pada pembelajaran matematika yang banyak disukai oleh mahasiswa. Pembelajaran adalah suatu upaya yang dilakukan oleh seorang guru atau pendidik untuk membelajarkan siswa yang belajar (Rahayu \& Firmansyah, 2019). Pembelajaran merupakan suatu proses tingkah laku dalam upaya meningkatkan kemampuan diri (Rangga \& Naomi, 2017). Model pembelajaran berbasis olahraga diharapkan dapat meningkatkan minat semangat mahasiswa dalam pembelajaran matematika (Rika Mulyati Mustika Sari, 2019).

Dalam belajar matematika konteks keseharian siswa sangat berperan penting, karena memudahkan siswa untuk menggunakan keterampilan membaca dan menjawab pertanyaan, dan dapat menantang pola berpikir matematis (Putra Hal| 67 et al., 2016).

Konteks sepakbola dalam pembelajaran matematika dapat dijadikan sumber belajar maupun rekreasi matematika yang dapat menumbuh kembangkan rasa ingin tahu dan berpikir reflektif/kritis siswa. Banyak sekali aspek penting dalam konteks sepakbola (Soccer/Football) yang dapat dikaitkan dengan pembelajaran matematika diantaranya berkaitan dengan topik bilangan, geometri hingga peluang. (Muh. Farid Wajdih, 2020).

Untuk menghubungkan kegiatan bermain dengan konsep yang akan dipelajari,orientasi kegiatan bermain secara matematis sangat penting. Pada tahap ini anak akan dibiasakan menyelesaikan masalah sehari-hari tanpa harus mengaitkan secara tergesa-gesa pada matematika formal. Anak akan memodelkan secara situasi permasalahan matematika yang berhubungan dengan konteks yang diberikan (Batubara, 2018). 
Berdasarkan analisis situasi, bahwa permasalahan selama ini pada ilmu matematika dan ilmu olahraga merupakan bidang ilmu pengetahuan yang berdiri sendiri. Ilmu olahraga dan ilmu matematika merupakan bidang ilmu yang bermanfaat bagi kehidupan manusia, akan tetapi permasalahan yang timbul karena manusia mengalami kesulitan dalam menerapkan ilmu matematika dalam praktek aktivitas cabang olahraga begitu juga sebaliknya. Padahal jika olahraga bisa dikaitkan dalam matematika, maka dapat meningkakan prestasi keduanya.

Menyikapi masa Pandemi Covid-19 saat ini, pembelajaran daring menjadi salah satu solusi dalam pembelajaran, sehingga permainan sepakbola yang dapat diakses secara live maupun highlight dapat dijadikan konten dalam pembelajaran daring. Berdasarkan penjelasan di atas, penulis mengaitkan antara olahraga dan sains (matematika) ke dalam cabang olahraga sepakbola. Pertanyaan yang mucul dalam dunia pendidikan yaitu apakah ada relevansi antara ilmu matematika dalam prakek kegiatan olahraga.
Tim penulis terdiri dari kedua Program Studi Pendidikan Matematika dan Program Studi Pendidikan Olahraga bekerjasama dengan Program Studi Hal| 68 Pendidikan Matematika Universitas Muhammadiyah Pringsewu melalui Lembaga Penelitian dan Pengabdian Masyarakat (LPPM) Universitas Muhammadiyah Bangka Belitung akan mengadakan PKM Kolaborasi tentang Webinar Pembelajaran Daring Matematika Dalam Olahraga Sepakbola Mahasiswa.

Berdasarkan analisis situasi, dapat diidentifikasi beberapa permasalahan, yaitu 1) Mahasiswa masih beranggapan bahwa ilmu matematika dan ilmu olahraga merupakan bidang ilmu yang berdiri sendiri sehingga tidak bisa dikaitkan ataupun dipadukan satu sama lain, 2) Masih minimnya penelitian-penilitian yang mengkolaborasikan antara ilmu olahraga dengan ilmu matematika khususnya pada cabang olahraga sepakbola, 3) Dalam pembelajaran matematika, belum mengkaitkan dengan konteks olahraga sepakbola, 4) Relevansi antara ilmu matematika dan olahraga dalam permainan sepakbola. 
Untuk memecahkan masalah yang diajukan di atas, maka kegiatan yang akan dilakukan berupa PKM Kolaborasi dengan cara webinar pembelajaran daring tentang matematika dalam olahraga sepakbola bagi mahasiswa Pendidikan Matematika Universitas Muhammadiyah Pringsewu dan mahasiswa Pendidikan Matematika dan Pendidikan Olahraga Universitas Muhamamdiyah Bangka Belitungyang bertujuan untuk menjadi bahan referensi dalam pembelajaran matematika dan olahraga.

\section{METODE}

Metode yang digunakan dalam program Pengabdian Kepada Masyarakat (PKM) ini tentang Webinar Pembelajaran Daring Matematika dalam Sepakbola yang dilaksanakan secara bersama atau kerjasama antara Universitas Muhammadiyah Pringsewu dan Universitas Muhammadiyah Bangka Belitung. Metode yang digunakan yaitu metode daring/online. Metode ini diambil karena sesuai dengan keadaan kondisi pandemi covid 19 saat ini dan disesuaikan dengan tujuan pengabdian berupa pembelajaran daring. Pelaksanaan pengabdian masyarakat ini menggunakan platform zoom. Penggunaan platform zoom ini karena media ini dapat digunakan secara efektif dan tanpa harus tatap muka secara langsung dan dapat diterapkan dalam pembelajaran online. Kegiatan Pengabdian Kepada Masyarakat ini dilakukan dalam beberapa tahap atau prosedur kerja, yaitu:

\section{Tahap Perencanaan}

Pada tahap ini dilakukan perencanaan kegiatan pengabdian dengan menentukan subjek kegiatan, melakukan kerjasama dengan mitra, dan menentukan materi pelaksanaan. Selain itu pada tahap ini dilakukan rencana luaran yang akan dihasilkan dalam kegiatan.

\section{Tahap Pelaksanaan}

Pada tahap ini dilakukan kegiatan pengabdian masyarakat dengan melakukan webinar secara online sesuai dengan metode kegiatan.

Webinar ini dibagi dalam beberapa tahap, yaitu: a) Ceramah, metode ini digunakan untuk menyampaikan materi tentang olahraga sepakbola, dan materi matematika yang dikaitkan dengan ilmu olahraga sepakbola. Selain itu tahap ini dijelaskan bagaimana melakukan pembelajaran daring pada pembelajaran 
matematika dengan mengkaitkan ilmu olahraga sepakbola, b) Diskusi, metode diskusi dilakukan dengan memberikan suatu permasalahan matematika berdasarkan konteks olahraga sepakbola, untuk dibahas dan dipecahkan bersama, c) Tanya jawab, metode tanya jawab dilakukan dengan memberikan pertanyaan yang harus dijawab kepada peserta, tanya jawab ini dilakukan sebagai pendorong peserta untuk melakukan penelusuran lebih lanjut,d) Penugasan, metode ini dilakukan untuk mendorong peserta melakukan tindakan kreatif dengan membuat permasalahan matematika yang dikaitkan dengan permasalahan konteks sepakbola.

\section{Tahap Evaluasi}

$$
\text { Pada tahap ini dilakukan }
$$
pengamatan secara langsung pada saat kegiatan.Selain itu tahap evaluasi digunakan untuk melihat tingkat keberhasilan peserta dalam memahami materi melalui penugasan yang diberikan, sehingga didapatkan data yang lengkap mengenai keberhasilan kegiatan ini.

Kegiatan ini dilaksanakan selama satu hari pada bulan September 2020.
Peserta kegiatan adalah mahasiswa dari Universitas Muhammmadiyah Bangka Belitung dan Universitas Muhammmadiyah Pringsewu, Guru SD, Hal| 70 dan Dosen dari Universitas lainnya dengan jumlah sebanyak 112 peserta. Pengukuran keberhasilan kegiatan diukur dari hasil angket kesemua peserta dan wawancara beberapa peserta untuk mengetahui respon peserta dalam kegiatan ini.

\section{HASIL DAN PEMBAHASAN}

Kegiatan Pengabdian Kepada Masyarakat dilaksanakan pada hari Selasa, 29 September 2020. Kegiataan ini dilakukan secara daring dengan menggunakan paltform zoom yang diikuti sebanyak 112 peserta dengan rincian peserta dari Universitas Muhammadiyah Surabaya sebanyak 1 orang, Universitas Pendidikan Muhammadiyah Sorong sebanyak 1 orang, Guru SD Negeri 12 Pemali sebanyak 1, dan Universitas Muhammadiyah Pringsewu sebanyak10 orang, dan 99 peserta berasal dari Universitas Muhammadiyah Bangka Belitung.

Berdasarkan hasil angket yang diberikan kepada seluruh peserta 
didapatkan data seperti pada tabel 1 pergurua tinggi lainnya yang tidak berikut.: menyertakan jurusannya.

\begin{tabular}{|l|l|c|c|c|c|c|}
\hline NO & \multicolumn{1}{|c|}{ Pertanyaan } & $\begin{array}{c}\text { SK } \\
\mathbf{( \% )}\end{array}$ & $\begin{array}{c}\text { K } \\
\mathbf{( \% )}\end{array}$ & $\begin{array}{c}\text { C } \\
\mathbf{( \% )}\end{array}$ & $\begin{array}{c}\text { B } \\
\mathbf{( \% )}\end{array}$ & $\begin{array}{c}\text { SB } \\
\mathbf{( \% )}\end{array}$ \\
\hline $\mathbf{1}$ & $\begin{array}{l}\text { Tema webinar } \\
\text { relevan dengan } \\
\text { bidang anda }\end{array}$ & 1 & 0 & 10 & 58 & 43 \\
\hline $\mathbf{2}$ & $\begin{array}{l}\text { Kegiatan } \\
\text { webinar berjalan } \\
\text { dengan baik }\end{array}$ & 1 & 0 & 8 & 53 & 50 \\
\hline $\mathbf{3}$ & $\begin{array}{l}\text { Tujuan webinar } \\
\text { jelas }\end{array}$ & 1 & 0 & 5 & 51 & 54 \\
\hline $\mathbf{4}$ & $\begin{array}{l}\text { Panitia Telah } \\
\text { bekerja } \\
\text { professional }\end{array}$ & 1 & 0 & 4 & 56 & 51 \\
\hline $\mathbf{5}$ & $\begin{array}{l}\text { Anda merasa } \\
\text { puas mengikuti } \\
\text { webinar ini }\end{array}$ & 1 & 1 & 11 & 51 & 48 \\
\hline $\mathbf{6}$ & $\begin{array}{l}\text { Penyebaran } \\
\text { informasi } \\
\text { pelaksanaan } \\
\text { webinar }\end{array}$ & 1 & 0 & 7 & 60 & 44 \\
\hline $\mathbf{7}$ & $\begin{array}{l}\text { Kelengkapan } \\
\text { sarana dan } \\
\text { prasarana }\end{array}$ & 1 & 0 & 20 & 58 & 33 \\
\hline
\end{tabular}

Tabel 1. Respon Peserta

Berdasarkan tabel 1, bahwa sebanyak 112 peserta telah memberikan respon mengenai kegiatan pengabdian masyarakat sebanyak $38,39 \%$ peserta menyatakan bahwa tema webinar sangat relevan dengan bidangnya, dan 51,78\% menyatakan relevan, $8,92 \%$ cukup relevan dan ada 1 subjek atau 0,89\% menyatakan sangat kurang relevan dengan bidangnya. Berdasarkan analisis peserta bahwa kegiaan ini tidak hanya diikuti oleh mahasiswa pendidikan matematika tetapi ada dari mahasiswa Pendidikan Guru Sekolah Dasar, Pendidikan Jasmani Kesehatan dan Rekreasi, Guru SD, dan mahasiswa dari
Selanjutnya berdasarkan kategori tentang proses pengabdian sebanyak Hal|71 $44,64 \%$ peserta menyataka sangat baik, 47,32\% menyatakan baik, 7,14\% cukup baik, dan 0,89\% sangat kurang. Dilihat dari jumlah responden yang menyatakan baik dan sangat baik mencapai 91,96\% maka dapat disimpulkan bahwa kegiatan pengabdian dengan tema webinar pembelajaran daring matematika dalam olahraga sepakbola dapat dinyatakan berjalan dengan lancar atau baik. Ini tidak lepas dari dukungan semua pihak yang turutmembantu dalam kegiatan ini. Selain itu materi yang disampaikan sesuai dengan bidang ilmu masing-masing pemateri.

Kategori pada tujuan webinar yang jelas bahwa $48 \%$ peserta menyatakan sangat jelas, 45,53 jelas, 4,46 cukup jelas, dan $0,89 \%$ peserta menyatakan kurang jelas. Selanjutnya sebanyak 45,53\% menyatakan bahwa panitia telah bekerja sangat profesional, $50 \%$ menyatakan profesional, 3,57 cukup profesional, dan 0,89\% kurang profesional.

Kategori penyebaran informasi pelaksanaan bahwa sebanyak 39\% peserta 
menyatakan sangat jelas, dan 53,57 merasa jelas. Sedangkan, untuk kategori kelengkapan sarana dan prasarana dalam kegiatan pengabdian ini sebanyak 29,46 peserta merasa angat lengkap, dan 51,79 peserta menyatakan lengkap.

Kepuasan peserta dalam kegiatan pengabdian masyarakat ini sebanyak 42,86 merasa sangat puas, 45,54 puas, dan 9,82 cukup puas, dan 0,89 merasa kurang puas.

Dilihat dari jumlah persentase kepuasan peserta yang menyatakan puas mencapai $88,40 \%$ berarti dapat dinyatakan bahwa pembelajaran matematika dikaitkan dengan sepakbola sangat baik dalam pembelajaran.

Berdasarkan hasil wawancara sebanyak lima subjek menyatakan bahwa, 1) Webinar ini memberikan suatu pengetahuan bahwa antara pelajaran satu dengan yang lain ada keterkaitan atau saling berhubungan, seperti tema matematika dalam olahraga sepak bola. Olahraga sepak bola banyak sekali mengandung aspek matematika seperti dijelaskan oleh narasumber. Mulai dari bentuk lapangan, peluang pemain, dan lain sebagainya. Selain itu tadi juga dijelaskan bahwa dalam penerapan pembelajaran kolaborasi seperti ini kita sebagai calon guru harus memiliki niat ikhlas dan menguasai konsep dasar pelajaran tersebut, dengan demikian kemungkinan keberhasilan dalam pembelajaran akan tercapai.

2) Peserta yang mengikuti webinar ini menjadi tahu bahwa ada beberapa aspek matematika yang berhubungan dengan olahraga seperti materi tentang bilangan, geometri, hingga peluang karna ini belum pernah ada penjelasan yang rinci tentang hubungan matematika dengan olahraga, peserta merasa menjadi lebih bersemangat untuk mempelajari matematika dalam aspek apapun, karna penulis tidak menyadari bahwa matematika memainkan peran yang sangat penting dalam kehidupan sehari hari khususnya olahraga. Terima kasih atas semua materi yang disampaikan oleh para dosen,benar-benar bermanfaat.

3) Tentang webinar ini diketahui bahwa matematika itu luas dan mencakup semua aspek terutama sepakbola, dengan mengikuti kegiatan webinar peserta mendapatkan pengetahuan bahwa matematika bisa dihubungkan dengan sepakbola seperti adanya volume,jari, 
tinggi,lebar,dan luas. Berdasarkan hasil angket bahwa peserta menganggap olahraga tidak ada sangkutpautnya dengan matematika, namun setelah mengikuti webinar math $\mathcal{E}$ soccer olahraga memiliki hubungannya dalam pembelajaran matematika.

4) Kegiatan webinar ini memberikan pemahaman bagaimana membuat kegiatan pembelajaran menjadi menyenangkan khususnya pembelajaran matematika yang sering dianggap sulit bagi siswa dengan dipadukan pada pembelajaran olahraga sepak bola. Sebelumnya tidak terpikirkan bahwa pembelajaran matematika dapat dipadukan dengan olahraga sepakbola. Akan tetapi, setelah mengikuti webinar muncul inspirasi bahwa pembelajaran matematika bisa dipadukan dengan konteks pembelajaran lain secara luas. Sehingga, konsep belajar sambil bermain dapat lebih diterapkan pada siswa untuk membangkitkan semangat siswa dalam pembelaajran matematika dengan memadukan antara praktek dengan teori.

5) pada kegiatan webinar ini materri yang di dapatkan adalah pembelajaran sepakbola serta mempelajari matematika, dapat meningkatkan rasa kepercayaan diri siswa terhadap pelajaran matematika, sebab banyak siswa yang sulit dan kurang berminat dalam pelajaran matematika,dengan terdapatnya konteks pelajaran matematika didalam pelajaran sepakbola dapat membuat siswa memahami pelajaran matematika tersebut.

\section{SIMPULAN}

Berdasarkan pengabdian masyarakat yang telah dilakukan diperoleh bahwa kegiatan pengabdian tentang webinar pembelajaran matematika dalam olahraga sepakbola telah berjalan dengan baik menggunakan platform Zoom dan peserta merasa puas dalam mengikuti kegiatan, ini tidak terlepas dari kesiapan panitia dalam mempersiapkan kegiatan dan kelengkapan sarana dan prasarana yang mendukung.

Selanjutnya peserta menyatakan bahwa materi yang disampaikan memberikan gambaran bahwa dalam pembelajaran matematika dapat dikaitkan dengan kehidupan sehari-hari, seperti matematika dengan olahraga sepakbola. Sehingga mendapatkan gambaran dalam pembelajaran sehingga dapat menyenangkan dengan mengaitkan permainan dalam pembelajaran 
matematika, hal ini didukung oleh penelitian, Adnyana \& Sujadi (2015) bahwa pembelajaran dengan metode Sepak Bola Verbal dapat meningkatkan minat dan prestasi belajar matematika siswa. Sehingga kami sarankan bahwa dalam pembelajaran matematika sangat baik apabila dikaitkan dengan permainan keseharian siswa seperti olehraga sepakbola.

\section{DAFTAR PUSTAKA}

Batubara, H. H. (2018). Pengembangan Media Pembelajaran Matematika berbasis Android untuk Siswa SD/MI. Muallimuna: Jurnal Madrasah Ibtidaiyah, 3(1), 12.

https://doi.org/10.31602/muallimuna.v $3 i 1.952$

Handoko, A. H. (2018). Analisis

Kemampuan Teknik Dasar Pemain Sepak Bola. Jorpres (Jurnal Olahraga Prestasi).

Muh. Farid Wajdih. (2020). META-

ANALISIS PEMBELAJARAN

PENDIDIKAN MATEMATIKA

REALISTIS (RME) TERHADAP HASIL BELAJAR MATEMATIKA. Journal of Islamic Education.

Nugrahadi, E. W., Maipita, I., Ane, L., \& Putra, P. D. (2018). ANALISIS IMPLEMENTASI KURIKULUM BERBASIS KKNI DI FAKULTAS EKONOMI UNIMED. NIAGAWAN, 7(1). https://doi.org/10.24114/niaga.v7i1.934 9
Purwanti, P., \& Yusuf, A. (2018). Studi evaluasi efektivitas pelaksanaan praktik pengalaman lapangan (PPL) mahasiswa Program Studi Bimbingan dan Konseling FKIP UNTAN Pontianak tahun 2017. Proceedings Hal| 74 International Conference on Teaching and Education (ICOTE).

Putra, Y. Y., Zulkardi, Z., \& Hartono, Y. (2016). Pengembangan Soal Matematika Model PISA Level 4, 5, 6 Menggunakan Konteks Lampung. Kreano, Jurnal Matematika KreatifInovatif, 7(1), 10-16.

https://doi.org/10.15294/kreano.v7i1.4 832

Rahayu, G. D. S., \& Firmansyah, D. (2019). PENGEMBANGAN PEMBELAJARAN INOVATIF BERBASIS PENDAMPINGAN BAGI GURU SEKOLAH DASAR. Abdimas Siliwangi, 1(1), 17. https://doi.org/10.22460/as.v1i1p1725.36

Rangga, M., \& Naomi, P. (2017). Pengaruh Motivasi Diri terhadap Kinerja Belajar Mahasiswa. Jurnal Psikologi Paramadina.

Rika Mulyati Mustika Sari. (2019). Penerapan Pendekatan Creative Problem Solving Dalam Peningkatan Kemampuan Berpikir Kritis Matematis Pada Mahasiswa Program Studi Pendidikan Matematika Fkip Unsika. Talenta Conference Series: Science and Technology (ST). https://doi.org/10.32734/st.v2i2.542 